\title{
The Outdoor Learning Modules Based on Traditional Games in Improving Prosocial Behaviour of Early Childhood
}

\author{
Junaedah $^{1}$, Syamsul Bahri Thalib ${ }^{1} \&$ Muhammad Arifin Ahmad ${ }^{1}$ \\ ${ }^{1}$ Post Graduate Program of Educational Science, State University of Makassar, Indonesia \\ Correspondence: Andi Asrifan, Faculty of Teachers Training and Education, Universitas Muhammadiyah \\ Sidenreng Rappang, Jalan Angkatan 45 Nomor. 1A Lt. Salo, Rappang, Kabupaten Sidenreng Rappang, South \\ Sulawesi, Indonesia.
}

Received: March 8, 2020

doi:10.5539/ies.v13n10p88
Accepted: April 29, $2020 \quad$ Online Published: September 21, 2020

URL: https://doi.org/10.5539/ies.v13n10p88

\begin{abstract}
Working outside can be harder than inside; one may be physically more active, regularly battling against the elements and often more alert - watchful for potential dangers. Overall education out of doors is physically and mentally taxing. We have to be convinced all the effort is for a good reason (Bilton, 2010, p. 12). The researchers applied the mixed method with covergent parallel design (Creswell, 2016). The results showed that 1) The initial description of prosocial behaviour of young children in Joy Kids Kindergarten, Mangasa Subdistrict, Tamalate Makassar District, showed that teachers paid attention to improve and look for activities in the form of play so that things that were worse towards prosocial behaviour of children could be avoided. 2) The traditional game-based outdoor learning module produced has been accepted from the results of an assessment of the utility, feasibility and accuracy, carried out by two experts in the field of education and an education practitioner. 3) The traditional game-based outdoor learning module that is produced affects the development of prosocial behaviour of young children. Based on the validator's evaluation, it is declared valid to be used, its practical value is feasible to be used in the field without the need for revision, and all the devices previously presented can be declared valid for use.
\end{abstract}

Keywords: outdoor learning module, traditional games, child prosocial behaviour

\section{Introduction}

Early Childhood Education/Pendidikan Anak Usia Dini (PAUD) is a process of fostering the growth and development of children from birth to six years as a whole, which includes physical and non-physical aspects by providing stimulation for physical, spiritual (moral and spiritual) development, motor, mind, emotional, and the right and correct prosocial so that children can grow and develop optimally. The efforts made include intellectual stimulation, maintenance of healthy nutrition, and providing broad opportunities to explore and learn actively.

As stated in Law Number 20 Year, 2003 concerning the National Education System states that Early Childhood Educationis:

A coaching effort aimed at children from birth until the age of six carried out through the provision of educational stimuli to help growth and physical and spiritual development so that children have the readiness to enter further education (article 1 paragraph 1)

Education in the family environment is the most basic education because children first recognized that environment. However, at the age of 4 years, children begin to be less satisfied with only hanging out with family and want to expand relationships with members of the nearest community. This is what triggers parents to provide freedom of association with the community, but that has educational value, namely by including children in educational institutions known as kindergartens. Patterns of social behaviour or behaviour that are not prosocial are fostered in early childhood or during the formation of character; early prosocial experiences determine personality after children become adults. The many experiences of happiness encourage children to look for their experiences again to become people who have prosocial nature. The number of unpleasant experiences may lead to an unhealthy attitude towards prosocial experiences and towards people in general. Unpleasant experiences that are too much also encourage children not prosocial and anti-prosocial.

Early age is the age of play, the age at which children imitate what they see, they learn from what they see. Introducing the environment to young children is the first step in shaping their behaviour. Introducing the 
environment in early childhood is usually with Outdoor learning. Through Outdoor learning, it is expected to be able to develop students' prosocial behaviour. Prosocial behaviour that is expected to occur in students including being able to work with people around them, independence, and responsibility.

The Joy Kids Kindergarten is one of a target school in this research which is located in Makassar. In Joy Kids Kindergarten shows the condition of the students wants to play alone, do not want to share toys with fellow friends, even do not care about the condition of other students, in the sense that the prosocial behaviour of students in Kindergarten Joy Kids is still categorized as low. Students in Joy Kids Kindergarten which incidentally lead to modern games (online) obtained from their environment. Being outdoors and experiencing nature is often believed to cultivate children's positive attitudes towards the environment and their willingness to protect it and live in a more sustainable way (Chawla, 2007; Davis, 2010; Louv, 2010 cited in Norðdahl \& Jóhannesson, 2016).

Outdoor learning can be defined as learning in an outdoor context based on experiences and interactions with physical and cultural phenomena. Outdoor learning is relevant in that it is a reality each of us has a connection to but has not been fully vetted for use across educational contexts. This entry examines the differences between outdoor education and outdoor learning, looks at what it means to learn in an outdoor setting, and provides examples of outdoor learning from both informal and formal educational contexts (Peppler, 2017).

Husamah (2013, p. 22) in Arizandi (2018) points out that outdoor learning is a learning process that is designed to allow students to learn direct learning materials on the actual object, so the learning will be more obvious. The advantages of outdoor learning strategy were the students could encourage their motivation in learning with a fun learning environment, use of instructional media that concrete, using natural materials that already exist around, could foster the ability to explore and could give pleasure to the students when the study without feeling bored and tired because of lack of interest in the learning in teaching. Outdoor learning strategy could also foster the strengthening of the concept to be given to children. Learning in the outdoors has significant educational advantages for children in the Primary School years and the need to connect with nature is becoming increasingly prominent in research worldwide. Pro-environmental behaviour, especially in the early years, has been shown to have a causal relationship with connectivity with the natural environment (Lloyd \& Gray, 2014).

In other hand, outdoor learning can be defined as activities allow children to actively participate and to learn by doing. Learning requires a lot of work and activities (Yıldırım \& Akamca, 2017). In addition, Gair (1997) cited in (Yıldırım \& Akamca, 2017; Ayotte-Beaudet et al., 2017; Dillon et al., 2017) listed six features of an outdoor education programme:

1) Education occurs outdoor. It does not have to be offered in a classroom.

2) Participants get directly involved in activities.

3) Real objects are used. Activities are implemented by using real objects and the senses.

4) Instead of memorising available knowledge, relations between objects or events are discovered and described.

5) Learning through practice and experience activates more than one sense.

6) Since the environment of an outdoor education programme is different from that of an enclosed classroom, children find outdoor activities interesting and fun.

However, we still believe that it should be possible to find interesting invariants that could help teachers and researchers to get a better picture of the general possibilities, constraints, and opportunities of outdoor science teaching. In general, outdoor education can be described as teaching and/or learning and/or experiencing in an outdoor and/or out-of-school environment. The content of learning and teaching is therefore different and depends on the general aim of the programme, the target group and the outdoor setting, e.g., the gaining of knowledge in natural sciences; increased PA (physical activity), leadership skills, personal and social development; survival skills; and improved skills in relation to nature-oriented sports (Becker et al., 2017; Kervinen, Uitto, \& Juuti, 2018).

There are several types of traditional games that can explore and develop children's potential in a pleasant atmosphere in outdoor learning that very familiar in Indonesia especially in South Sulawesi, namely the game of ular naga, santo', asing, and saureka-reka but in carrying out the learning Joy Kids kindergarten must have a basis in the form of guidelines implementation or learning modules to help teachers carry out learning.

\subsection{The Nature of Prosocial Behavior}

Psychologists briefly define an understanding of prosocial behaviour. Prosocial behaviour is briefly defined as an action that is expected to benefit others (Tinne, 2012, p. 4). Prosocial behaviour is a form of behaviour that arises in 
social contact, so prosocial behaviour is an action taken or planned to help others without regard to the motives of the helper (Asih \& Pratiwi, 2010, p. 1).

Stated in Tinne (2012, p. 7), prosocial behaviour includes the following matters:

a) Sharing means the willingness of someone to share their feelings with others, both in an atmosphere of joy and sorrow.

b) Help, which means a person's willingness to provide assistance to those who need both material and moral assistance, including offering something that can support the implementation of the activities of others.

c) Cooperation, which means a person's willingness to cooperate with others to achieve a common goal, including mutual giving, mutual benefit.

d) Acting honestly means that someone is willing to act and say what they are, not to lie to others and not cheating on others.

e) Charity implies the willingness of someone to give part of their possessions voluntarily to someone in need.

Ferreira et al. (2016) said that "Prosocial behaviour is considered an important dimension of positive development". In child development, prosocial behaviour is the most important thing in child development. The same thing conveyed by Guo in his article that "Prosocial attitudes are one of the most important aspects of many positive mental qualities, as well as is important components of a sound personality and the promotion of individual socialization". Wu et al. (2016) suggested that: "Parent-child, gratitude and prosocial behaviour are a crucial impact on psychological development". The above explains that the importance of child prosocial behaviour in building parent and child relationships itself is the impact of social development.

Taylor and Zwaan (2008) suggested that the meaning of two main concepts, namely: Altruism (altruism) is a voluntary act to help others unconditionally, or want to just charity (Schroeder, Penner, Dovidio, \& Piliavin, 1995). Prosocial behaviour is a broader category (Batson, 1998). Prosocial behaviour for each action of the helper is a motive that has been designed to help others.

McGuire (1994) asked students to describe examples where they gave help and received help. They have no trouble mentioning 72 different types of helping behaviour, including ordinary help (giving directions, getting a falling newspaper), substantial help (lending money, helping others to pack), emotional help (listening to people express their problems) and help - emergency (bringing someone to the emergency room, pushing a broken car).

The social definition in the Big Indonesian Dictionary (Anonymous, 1989, p. 855) is "regarding the community, the need for communication, like paying attention to the public interest (like helping, receiving, etc.)". Social development according to Hurlock (2003, p. 250) means: Obtaining the ability to behave by social demands. Being a socially capable person (socialized) requires three processes. Each process is separate and very different from each other, but is interrelated, so a failure in a process will reduce the level of individual socialization.

\subsection{Module}

Wahab (2017) stated one of the module definitions, which is a printed teaching material designed to be studied independently by learning participants. The module is also called the media for independent learning because it has been equipped with instructions for self-study. That is, the reader can carry out learning activities without the presence of a teacher directly.

Modules are held to facilitate teachers in directing learning to achieve goals in learning. Head of State Administration Agency Regulation No. 5 of 2009, the module is interpreted as the smallest unit of a subject that can stand alone and be used independently in the learning process. Anwar (2010) states that learning modules are instructional materials that are arranged systematically and attractively that includes material content, methods and evaluations that can be used independently to achieve the expected competencies.

Sukiminian et al. (2015) writes in his article that module design (module development design) includes activities: 1) planning work time; 2) determine the material; 3 ) searching for supporting materials; 4) determine the order of presentation; 5) determine the type of validation to practice the questions and validate each subject; 6) determine the appropriate examples, pictures or graphics; and 7) design the outline and physical format.

Based on some of the opinions above, it can be concluded that the module can be used as a guide for teachers in outdoor play activities. This outdoor game learning module is a type of game that is intended to develop students' prosocial behaviour that is structured to assist teachers in implementing an active, creative and enjoyable learning process especially in early childhood education and can change teacher-centred learning habits to become centred on learners. 
The characteristics of a module are written by Parmin and Aminah (2009) as follows; preceded by a statement of learning objectives, knowledge is structured in such a way as to be able to actively encourage student participation, load an assessment system based on mastery, contain all elements of learning material and all learning tasks, provide opportunities for differences between individual students and lead to a complete learning goal.

According to the Directorate-General for Quality Improvement of Teachers and Education Personnel/Peningkatan Mutu Pendidik dan Tenaga Kependidikan (PMPTK) (2008) in Syahrir and Susilawati (2015), the module can be said to be good if there are the following characteristics:

a. Self Instructional

Through the use of modules, students are able to learn independently and are not always dependent on the teacher or other parties. To fulfil the Self Instructional character, the modules must meet the following criteria:

1) Contains clearly defined goals,

2) Loading learning material that is packaged into small units to facilitate learning thoroughly,

3) Contains examples and industries that support the clarity of presentation of learning materials,

4) Contains practice questions and assignments that allow students to respond and can measure their mastery level,

5) Contains contextual issues,

6) Use communicative and straightforward language,

7) Contains a summary of learning material,

8) Contains appraisal instruments that allow the use of self-assessment,

9) Contains feedback on assessments, so that their use knows the level of mastery of the material,

10) Provide information about references that support learning materials and modules.

\section{b. Self Contained}

All learning material from one competency unit or sub-competency that is studied is contained in a whole module. The purpose of this concept is to allow students to learn thoroughly, and the module can contain a series of planned and systematic learning activities.

c. Stand Alone

The modules developed do not depend on other media or do not have to be used together with other learning media. If the module is still related or still needs other media, then the module cannot be said to stand alone.

\section{d. Adaptive}

Modules can develop scientific and technological developments and are flexible to use; this is a module that is said to be Adaptive. Besides the adaptive module is if the contents of learning materials can be used up to a certain time.

\section{e. User-Friendly}

Wahab (2017) writes in his dissertation that the use of modules is often associated with self-instruction activities, so the consequences that must be met by the module are the completeness of the contents; this means that the content or presentation material of a module must be thoroughly discussed through the presentations so that the reader feels that he understands a particular field of study from the results of learning through this module. The purpose of writing the module in Wahab's (2017) dissertation is to write:

1) Clarify and facilitate the presentation of messages, so they are not too verbal.

2) Overcoming the limitations of time, space and senses, both study participants and lecturers/instructors.

3) Can be used precisely and varied, such as to increase motivation and enthusiasm for learning; develop the ability to interact directly with the environment and other learning resources that enable students to learn independently according to their abilities and interests.

4) Allows students to measure or evaluate their learning outcomes.

\subsection{Traditional Games}

According to the Indonesian dictionary, the game comes from the basic word "play" which means to do something for fun. Traditionally comes from the word "tradition" which means a custom that has been passed down from one generation to the present. While the word "traditional" means attitudes and ways of thinking and acting that hold 
fast to norms and customs that have been passed down for generations. Meanwhile According to Sukirman in Hasanah (2016) that the definition of traditional games is children's games from simple materials according to cultural aspects in people's lives.

According to Andriani (2012) that for children, playing has a very important benefit, playing is not only for fun but also a need that must be met. Then Andriani (2012) also stated that through play activities, children could learn about themselves, others and their environment. At a young age, children sometimes experience sensitive periods; children also sometimes begin to be sensitive about efforts to develop the full potential of the child. This period is a period in which children develop abilities including cognitive, moral values, and self-concept.

These days, traditional games are pushed aside by online games that take up a lot of children's time. Therefore what needs to be instilled in children is that traditional games are cultural assets that have the cultural characteristics of a nation, then behaviour can also be formed through traditional games from an early age. The characteristics of traditional games stated by Perdani (2013) in his article are:

"First, traditional games use the environment as a source of play and as a source of play. Second, traditional games are more often played with a busy number of players, although some can be played only in twos and threes. Third, traditional games have noble values and particular moral messages such as the values of togetherness, honesty, responsibility, grace (if you lose), encouragement of achievement, respect for others, intimacy, tolerance, active, creative, independence, concern for the environment, solidarity, sportsmanship, and obedience to the rules. Fourth, it has a flexible nature, which can be played indoors and outdoors (although more is played outdoors or on the field) and the rules of the game can be adjusted with the players' agreement. Fifth, the experience gained from the players is an emotional experience that is born from physical contact and eye contact as well as communication between players."

Then Andriani (2012) also wrote in his article about aspects of traditional games including: "a) physical aspects consisting of strength and endurance as well as flexibility; b) psychological aspects, which include elements of thinking, elements of calculation, intelligence, ability to make tactics, ability to overcome obstacles, memory, and creativity; c) social aspects include aspects of cooperation, love of order, respect, respect, and shame. "

According to Anne, which was downloaded on February 25, 2019, stated the influence and benefits of traditional games on children's mental development are:

1) Children become more creative.

2) Can be used as therapy for children.

3) Can be used as therapy for children.

4) Developing children's multiple intelligences

5) Developing children's natural intelligence.

6) Development of children's intelligence.

7) Developing children's musical intelligence.

8) Developing children's spiritual intelligence.

There are several types of games based on traditional games that can also help students to improve students' prosocial behaviour, namely:

1) "Ular Naga" Game

The Ular Naga Game is known to have existed since ancient times, a game that requires a lot of players is a game from generation to generation that is not the very clear origin and what is happening behind the game, which is certain this game has its historical value. The name of this game because in this game the player makes a long and lined line then each of them holds the shoulder of a friend who is likened to a snake, a dragon is the name of an animal whose existence is uncertain; clearly, the name of the snake is taken as a way of playing. This game only uses the field as a place to play "Ular Naga".

As for the Great Values in the Game of Ular Naga:

a) Excitement

b) Children learn to regulate their emotions to stay in cohesiveness.

c) Children obey the rules 
d) Hand in hand so that each other can not be separated and missed motion sway the snake.

After the learning process is complete, students are expected to be able to:

a) Develop an attitude of working together, the more opportunities they have to do things together, the faster they learn to do it by working together.

b) Develop an attitude of generosity by the child's willingness to share something with his friend

c) Developing children's sympathetic attitudes expressed through efforts to help fellow friends

d) Develop a selfless attitude and want to share what they have

2) Santo' Game

Santo' is a traditional children's game originating from the Makassar, South Sulawesi. The game 'Santo' is also commonly called Santo-santo or Massanto by the people of South Sulawesi. This folk game has various types depending on how to play. Santo' includes traditional games that are played in groups and are very easy to play.

High Value in Santo' Games:
a) Cooperation
b) Solidarity
c) Accuracy and Accuracy
d) Physical Freshness (sports)
e) Strategy Mapping
f) Social Interaction

After the learning process is complete, students are expected to be able to:

a) Develop an attitude of working together, the more opportunities they have to do things together, the faster they learn to do it by working together.

b) Develop an attitude of generosity by the child's willingness to share something with his friend

c) Developing children's sympathetic attitudes expressed through efforts to help fellow friends

d) Develop a selfless attitude and want to share what they have.

\section{3) Asing Game}

Nearly all regions in Indonesia are familiar with the Gobag Sodor game, only each region has a different name. The term Gobak Sodor is known in the area of Central Java. In the Natuna Islands known as the Galah, while in Riau it is known as the Galah Panjang, in the Riau Land area known as the Cak Bur or Main Belon. In West Java, the name of the game is Galah Asin, in Makassar it is called Asing and in the Batak Toba area, it is called Margala.

Asing Game is a group game consisting of two groups, where each team consists of 3-5 people. The point of the game is to block opponents from passing through to the last line back and forth and to achieve victory all group members must complete the process back and forth in the designated field area.

The values in the Asing game are as follows:

a) Togetherness;

b) Compact cooperation between one guard and another guard so that the opponent does not lose control to get out of our confines.

After the learning process is complete, students are expected to be able to:

a) Developing a cooperative attitude, the more opportunities they have to do things together, the faster they learn to do it by working together.

b) Develop an attitude of generosity through the child's willingness to share something with his friend.

c) Developing the attitude of sympathy of children expressed through efforts to help fellow friends.

d) Develop a selfless attitude and want to share what they have.

4) Saureka-reka game

Saureka Reka dance is very fun, actively involving children to play and dance together. This dance can be introduced to children as a play activity. The four bamboos function as gaba-gaba, a tool for this dance. At each bamboo tip, tie the bamboo segments that have been cut very tightly, using a rope. Tie tightly with the knot, and 
this bamboo-segment serves as a handle when playing bamboo so that the bamboo holder's hands are not pinched or injured. Better than the bamboo segments are sanded first so that the bamboo fibres do not hurt the player.

After the learning process is complete, students are expected to be able to:

a) Developing a cooperative attitude, the more opportunities they have to do things together, the faster they learn to do it by working together.

b) Develop an attitude of generosity through the child's willingness to share something with his friend.

c) Developing children's sympathetic attitudes expressed through efforts to help fellow friends.

d) Develop a selfless attitude and want to share what they have.

\subsection{Outdoor Learning}

Bloom's Taxonomy has three domains, namely: 1) Cognitive Domain. Huda (2013, p. 169) writes that include memories or recognition of certain facts, procedural patterns, and concepts that enable the development of intellectual abilities and skills; 2) Affective Domain. Nyoman (2013, p. 202) domain related to the development of feelings, attitudes, values and emotions; 3) Psychomotor domains, domains related to manipulative activities or motor skills. Utari (2012) wrote that Bloom's Taxonomy wrote 3 areas that were assessed in learning, namely cognitive, affective, and psychomotor. In these three domains, there are several assessment categories.

1) Cognitive Domains. The first three levels (bottom) are Lower Order Thinking Skills, while the next three levels are Higher Order Thinking Skills. However, making this level does not mean that the lower level is not important. Precisely lower-order thinking skills must be passed first to move up to the next level. This scheme only shows that the higher, the more difficult the ability to think

2) Affective Domain. There are five realm categories sorted from the simplest effective categories to complex behavioural categories, namely: a) Acceptance; b) Responsive; c) The value adopted (self-value); d) Organization; e) Characteristics.

3) Psychomotor domains. Psychomotor domains include physical movement and coordination, motor skills and physical abilities. This skill can be honed if you do it often. These developments can be measured in terms of speed, accuracy, distance, method of implementation. There are seven categories in the psychomotor domain ranging from simple to complex levels.

a) Perception; b) Readiness; c) Reaction directed; d) Natural reactions (mechanisms); e) Complex reactions; f) Adaptation; and g) Creativity.

Husamah (2013, p. 22) said Outdoor learning is also known by various other terms such as outdoor activities, outdoor study, field learning, or learning outside the classroom. Then according to Wulandari (in Gustiana, Ali, and Miranda, 2017) "outdoor learning" is an activity outside the classroom that makes learning outside the classroom interesting and fun, and more integrated with nature.

According to Neill (Nisa, 2015), several studies take the philosophy of Outdoor learning from outdoor education based on the doctrine of Comenius, Rousseau, and Pestalozzi, whose essence is as follows: that Comenius believes that learning from life experience is directly in contact with the natural environment so that it has feelings of, views, hearing, taste images, and touches that go directly to real objects, such as rain, fire, plants and so on. Furthermore, Rousseau (Nisa, 2015) emphasized that physical activity outside the room is very important in learning. To meet the curiosity and demands of students, education should be emphasized more on experiences related to the senses owned by students rather than using textbooks. Rousseau also stated that the first teachers in human life were feet, hands and eyes. Then Pestalozzi noted the same thing with Comenius and Rousseau that direct experience with real objects is a beginning lesson for students. Vera (2012, p. 107) describes the approach to learning outside the classroom into several sections, including the following: 1) Assignment Approach Method, 2) Question and Answer Approach Method, 3) Play Approach Method and 4) Observation Approach Method.

The definition of the game has been raised by many experts who are competent in their fields with a variety of views and clear boundaries. Games, according to Sujanto $(1996$, p. 28) are Spiritual food for children. He will not feel good if there is no chance to play around. Since they are still in the cradle, the child has started playing with his hands, feet, etc., then the child plays with the objects he gets around him; eventually, the child needs his tools to play with.

Based on some of the opinions above, it can be concluded that by implementing learning outside the classroom, the teacher does not play many roles, because students learn with their environment and sensory devices. Thus they will know how to make friends with nature. 


\subsection{Early Childhood Education Programs}

Law on National Education System Number 20 of 2003 Government Regulation on Early Childhood Education Article 1 Paragraph 1: Early Childhood Education, referred to as Pendidikan Anak Usia Dini (PAUD), is an effort to develop shown to children from birth to six years old through the provision of educational stimuli to help physical and spiritual growth and development so that children have the readiness to enter further education. (Sujiono, 2009, p. 6).

The opinion of Rachmawati who explains about the understanding of early childhood education is an education aimed at early childhood to stimulate every child's development and growth in preparation for entering further education (Khasanah et al., 2011) while Abdulhak (2002) argues that early childhood education is the most basic education for the formation of human resources in the future.

According to Rochma (2012) in his article writing understanding of Early Childhood is the figure of an individual who is undergoing a process of development very rapidly and is very fundamental for the next life. The nature of early childhood can be reviewed based on several dimensions, namely:

1) Review of children based on chronological age dimensions, limits on early childhood delivered by the NAEYC (National Association for Education of Young Children), Rochma (2012) states that early childhood are children who are in the age range between 0-8 years, which are covered by educational programs in child care parks, family daycare, private and public preschool education, kindergarten, and elementary school.

2) Children's review based on the philosophical point of view.

3) Overview of children based on the characteristics of its development, basically the development of children are things that also grow and develop in the whole child.

\subsection{Research Questions}

There are several types of traditional games that can explore and develop children's potential in a pleasant atmosphere outside the room (outdoor), namely the game of the Ular Tangga, Santo', Asing, and Saureka-Reka but in carrying out the learning Joy Kids kindergarten must have a basis in the form of guidelines implementation or learning modules to help teachers carry out learning. Based on the above problems, it can be made a formulation of problems relating to the development of Outdoor learning modules based on traditional games to improve prosocial behaviour of early childhood, namely:

1) How is the prosocial behaviour of young children in Joy Kids kindergarten Makassar?

2) What is the level of validity and practicality of Outdoor learning modules based on traditional games to improve prosocial behaviour of young children?

\section{Research Method}

\subsection{Research Design}

In this research, the researchers used mixed methods as research design. Creswell (2016) said that a mixed methods research design is a procedure for gathering, analyzing, and "mixing" quantitative and qualitative methods in one study or series of studies to understand a research problem. So this research design consists of a combination of using quantitative and qualitative methods to understand research problems. To obtain quantitative data, researchers used pre-test and post-test as instruments. However, in qualitative data the researcher used an observation checklist and questionnaire as an instrument. And type of mixed methods design in this reseach is the convergent parallel design. Convergent mixed methods design is to collect quantitative and qualitative data together, combine the data, and use the results to understand the research problem. The basic reason for this design is that one form of data collection supplies strengths to compensate for the weaknesses of the other forms, and that a more complete understanding of the research problem results from quantitative and qualitative data collection. For example, quantitative scores on instruments from many individuals provide the strength to compensate for the weaknesses of qualitative documents from several people. Or, qualitative and in-depth observations of some people offer strength in quantitative data that does not provide enough detailed information about the context in which individuals provide information. (Creswell, 2016) 


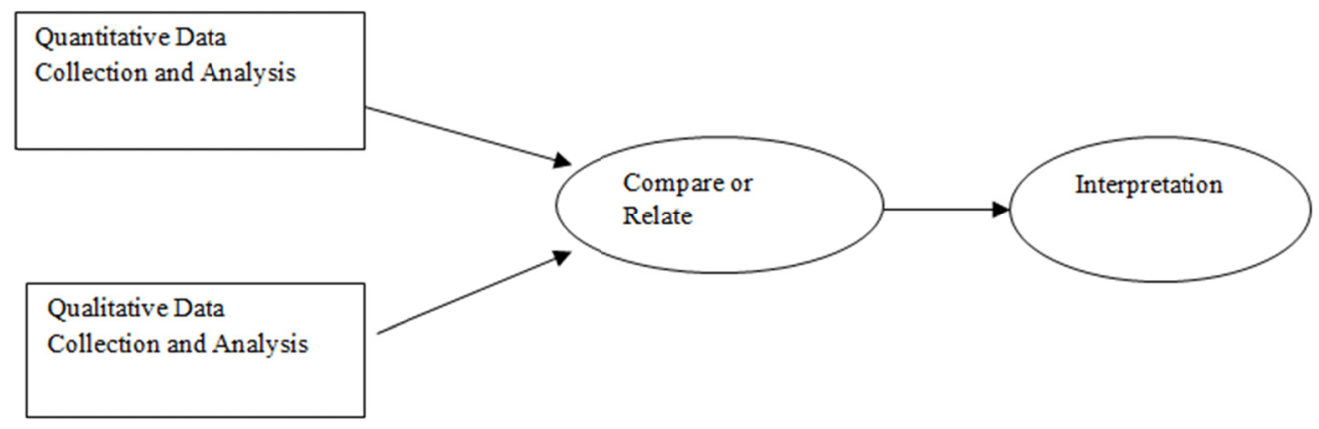

Figure 1. Convergent model in mixed methods research design

\subsection{Research Subject}

This research was carried out in Joy Kids Kindergarten, Mangasa Village, Tamalate District, Makassar. With (1) students aged 5-6 years (group B) with consideration that children aged 5-6 years have thought in exploring their world through stimulation provided by the teacher in the form of play as well as all aspects especially the development of child prosocial behaviour, and (2) Joy Kids Kindergarten teachers Mangasa Village Tamalate District Makassar.

\subsection{The Instrument of the Research}

The instruments used to determine the validity of traditional game-based Outdoor Learning Modules, namely: the validity of the traditional game-based Outdoor Learning Module product instruments include: (1) Interview validity test instruments, (2) The validity of traditional game-based outdoor learning observation sheet observation instruments, (3) The validity test instrument for the observation of children's activity,(4) The validity test instrument for the assessment of children's learning development, (5) The validity test instrument for the Outdoor Learning Module.

\section{Result}

How is the prosocial behaviour of young children in Joy Kids Kindergarten in Makassar?

Based on the results of observations with educators at Joy Kids Kindergarten, information was obtained that students' prosocial behaviour in learning, which is related to working with friends, likes to help friends in need, sharing with friends, and respecting friends has not been seen in students, so educators argue that by playing games outside the classroom can improve students' prosocial behaviour by using learning modules as a guide for implementing outdoor learning.

Table 1. Prosocial behavior data for joy kids kindergarten, Makassar outdoor learning through Ular Tangga game

\begin{tabular}{|c|c|c|c|c|c|c|c|c|c|c|c|c|c|c|c|c|}
\hline \multirow{3}{*}{$\begin{array}{c}\text { Level of Prosocial } \\
\text { Behavior }\end{array}$} & \multicolumn{8}{|c|}{ First Meeting } & \multicolumn{8}{|c|}{ Last Meeting } \\
\hline & \multicolumn{2}{|c|}{ Cooperation } & \multicolumn{2}{|c|}{ Helpful } & \multicolumn{2}{|c|}{ Share } & \multicolumn{2}{|c|}{$\begin{array}{l}\text { Appreciate } \\
\text { Friends }\end{array}$} & \multicolumn{2}{|c|}{ Cooperation } & \multicolumn{2}{|c|}{ Helpful } & \multicolumn{2}{|c|}{ Share } & \multicolumn{2}{|c|}{$\begin{array}{l}\text { Appreciate } \\
\text { Friends }\end{array}$} \\
\hline & $\mathrm{F}$ & $\%$ & $\mathrm{~F}$ & $\%$ & $\mathrm{~F}$ & $\%$ & $\mathrm{~F}$ & $\%$ & $\mathrm{~F}$ & $\%$ & $\mathrm{~F}$ & $\%$ & $\mathrm{~F}$ & $\%$ & $\mathrm{~F}$ & $\%$ \\
\hline Very well developed & - & - & - & - & - & - & - & - & 12 & 80 & 13 & 86.7 & 13 & 86.7 & 13 & 86.7 \\
\hline Develop accordingly & - & - & - & - & - & - & - & - & 3 & 20 & 2 & 13.3 & 2 & 13.3 & 2 & 13.3 \\
\hline Starts appearing & 3 & 20 & 5 & 33.3 & 6 & 40 & 4 & 26.7 & - & - & - & - & - & - & - & - \\
\hline Not yet appeared & 12 & 80 & 10 & 66.7 & 9 & 60 & 11 & 73.3 & - & - & - & - & - & - & - & - \\
\hline
\end{tabular}


Table 2. Prosocial behavior data for students of joy kids kindergarten, Makassar outdoor learning through Santo' games

\begin{tabular}{|c|c|c|c|c|c|c|c|c|c|c|c|c|c|c|c|c|}
\hline \multirow{3}{*}{$\begin{array}{c}\text { Level of Prosocial } \\
\text { Behavior }\end{array}$} & \multicolumn{8}{|c|}{ First Meeting } & \multicolumn{8}{|c|}{ Last Meeting } \\
\hline & \multicolumn{2}{|c|}{ Cooperation } & \multicolumn{2}{|c|}{ Helpful } & \multicolumn{2}{|c|}{ Share } & \multicolumn{2}{|c|}{$\begin{array}{c}\text { Appreciate } \\
\text { Friends }\end{array}$} & \multicolumn{2}{|c|}{ Cooperation } & \multicolumn{2}{|c|}{ Helpful } & \multicolumn{2}{|c|}{ Share } & \multicolumn{2}{|c|}{$\begin{array}{c}\text { Appreciate } \\
\text { Friends }\end{array}$} \\
\hline & $\mathrm{F}$ & $\%$ & $\mathrm{~F}$ & $\%$ & $\mathrm{~F}$ & $\%$ & $\mathrm{~F}$ & $\%$ & $\mathrm{~F}$ & $\%$ & $\mathrm{~F}$ & $\%$ & $\mathrm{~F}$ & $\%$ & $\mathrm{~F}$ & $\%$ \\
\hline Very well developed & - & - & - & - & - & - & - & - & 11 & 73.3 & 12 & 80 & 12 & 80 & 12 & 80 \\
\hline Develop accordingly & - & - & - & - & - & - & - & - & 4 & 26.7 & 3 & 20 & 3 & 20 & 3 & 20 \\
\hline Starts appearing & 3 & 20 & 3 & 20 & 2 & 13.3 & 3 & 20 & - & - & - & - & - & - & - & - \\
\hline Not yet appeared & 12 & 80 & 12 & 80 & 13 & 86.7 & 12 & 80 & - & - & - & - & - & - & - & - \\
\hline
\end{tabular}

Table 3. Prosocial behavior data for students of kindergarten joy kids Makassar city outdoor learning through Asing games

\begin{tabular}{|c|c|c|c|c|c|c|c|c|c|c|c|c|c|c|c|c|}
\hline \multirow{3}{*}{$\begin{array}{c}\text { Level of Prosocial } \\
\text { Behavior }\end{array}$} & \multicolumn{8}{|c|}{ First Meeting } & \multicolumn{8}{|c|}{ Last Meeting } \\
\hline & \multicolumn{2}{|c|}{ Cooperation } & \multicolumn{2}{|c|}{ Helpful } & \multicolumn{2}{|c|}{ Share } & \multicolumn{2}{|c|}{$\begin{array}{l}\text { Appreciate } \\
\text { Friends }\end{array}$} & \multicolumn{2}{|c|}{ Cooperation } & \multicolumn{2}{|c|}{ Helpful } & \multicolumn{2}{|c|}{ Share } & \multicolumn{2}{|c|}{$\begin{array}{c}\text { Appreciate } \\
\text { Friends } \\
\end{array}$} \\
\hline & $\mathrm{F}$ & $\%$ & $\mathrm{~F}$ & $\%$ & $\mathrm{~F}$ & $\%$ & $\mathrm{~F}$ & $\%$ & $\mathrm{~F}$ & $\%$ & $\mathrm{~F}$ & $\%$ & $\mathrm{~F}$ & $\%$ & $\mathrm{~F}$ & $\%$ \\
\hline Very well developed & - & - & - & - & - & - & - & - & 10 & 67 & 12 & 80 & 11 & 73.3 & 12 & 80 \\
\hline Develop accordingly & 1 & 6.7 & - & - & 2 & 13.3 & 1 & 6.7 & 5 & 33 & 3 & 20 & 4 & 26.7 & 2 & 13.3 \\
\hline Starts appearing & 3 & 20 & 5 & 33 & 2 & 13.3 & 4 & 26.7 & - & - & - & - & - & - & 1 & 6.7 \\
\hline Not yet appeared & 11 & 73.3 & 10 & 67 & 11 & 73.3 & 10 & 66.7 & - & - & - & - & - & - & - & - \\
\hline
\end{tabular}

Table 4. Prosocial behavior data for kindergarten students joy city Makassar outdoor learning through Saureka-reka game

\begin{tabular}{|c|c|c|c|c|c|c|c|c|c|c|c|c|c|c|c|c|}
\hline \multirow{3}{*}{$\begin{array}{l}\text { Level of Prosocial } \\
\text { Behavior }\end{array}$} & \multicolumn{8}{|c|}{ First Meeting } & \multicolumn{8}{|c|}{ Last Meeting } \\
\hline & \multicolumn{2}{|c|}{ Cooperation } & \multicolumn{2}{|c|}{ Helpful } & \multicolumn{2}{|c|}{ Share } & \multicolumn{2}{|c|}{$\begin{array}{l}\text { Appreciate } \\
\text { Friends } \\
\end{array}$} & \multicolumn{2}{|c|}{ Cooperation } & \multicolumn{2}{|c|}{ Helpful } & \multicolumn{2}{|c|}{ Share } & \multicolumn{2}{|c|}{$\begin{array}{c}\text { Appreciate } \\
\text { Friends } \\
\end{array}$} \\
\hline & $\mathrm{F}$ & $\%$ & $\mathrm{~F}$ & $\%$ & $\mathrm{~F}$ & $\%$ & $\mathrm{~F}$ & $\%$ & $\mathrm{~F}$ & $\%$ & $\mathrm{~F}$ & $\%$ & $\mathrm{~F}$ & $\%$ & $\mathrm{~F}$ & $\%$ \\
\hline $\begin{array}{l}\text { Very well } \\
\text { developed }\end{array}$ & - & - & - & - & - & - & - & - & 11 & 73.3 & 10 & 66.7 & 12 & 80 & 10 & 66.7 \\
\hline $\begin{array}{c}\text { Develop } \\
\text { accordingly } \\
\end{array}$ & - & - & - & - & - & - & 1 & 6.7 & 4 & 26.7 & 5 & 33.3 & 3 & 20 & 5 & 33.3 \\
\hline Starts appearing & 5 & 33.3 & 5 & 33.3 & 4 & 26.7 & 3 & 20 & - & - & - & - & - & - & - & - \\
\hline Not yet appeared & 10 & 66.7 & 10 & 66.7 & 11 & 73.3 & 11 & 73.3 & - & - & - & - & - & - & - & - \\
\hline
\end{tabular}

Table 5. Observation results of student activity in Ular Tangga game first meeting

\begin{tabular}{|c|c|c|c|c|c|c|c|c|c|c|c|}
\hline \multirow{3}{*}{ No } & \multirow{3}{*}{ Assessment Aspects } & \multicolumn{10}{|c|}{ SCORE } \\
\hline & & \multicolumn{2}{|r|}{1} & \multicolumn{2}{|r|}{2} & \multicolumn{2}{|c|}{3} & \multicolumn{2}{|r|}{4} & \multicolumn{2}{|c|}{5} \\
\hline & & $\mathrm{F}$ & $\%$ & $\mathrm{~F}$ & $\%$ & $\mathrm{~F}$ & $\%$ & $\mathrm{~F}$ & $\%$ & $\mathrm{~F}$ & $\%$ \\
\hline 1 & Presence & - & - & - & - & - & - & - & - & 15 & 100 \\
\hline 2 & Punctuality & 4 & 26.7 & 6 & 40 & 3 & 20 & 2 & 13.3 & - & - \\
\hline 3 & Readiness & 8 & 53.3 & 1 & 6.7 & 4 & 26.7 & 2 & 13.3 & - & - \\
\hline 4 & activity & 9 & 60 & 1 & 6.7 & 5 & 33.3 & - & - & - & - \\
\hline 5 & Child attention & 8 & 53.3 & 7 & 46.7 & - & - & - & - & - & - \\
\hline 6 & Enthusiastic & 9 & 60 & 6 & 40 & - & - & - & - & - & - \\
\hline 7 & How to play children & 8 & 53.3 & 3 & 20 & 4 & 26.7 & - & - & - & - \\
\hline 8 & Seriousness & 7 & 46.7 & 7 & 46.7 & 1 & 6.7 & - & - & - & - \\
\hline 9 & Structured play & 8 & 53.3 & - & - & - & - & - & - & - & - \\
\hline 10 & Children's activity & 6 & 40 & - & - & - & - & - & - & - & - \\
\hline
\end{tabular}


Table 6. Observation results of student activity in Ular Tangga game last meeting

\begin{tabular}{|c|c|c|c|c|c|c|c|c|c|c|c|}
\hline \multirow{3}{*}{ No } & \multirow{3}{*}{ Assessment Aspects } & \multicolumn{10}{|c|}{ SCORE } \\
\hline & & \multicolumn{2}{|c|}{1} & \multicolumn{2}{|c|}{2} & \multicolumn{2}{|c|}{3} & \multicolumn{2}{|c|}{4} & \multicolumn{2}{|c|}{5} \\
\hline & & $\mathrm{F}$ & $\%$ & $\mathrm{~F}$ & $\%$ & $\mathrm{~F}$ & $\%$ & $\mathrm{~F}$ & $\%$ & $\mathrm{~F}$ & $\%$ \\
\hline 1 & Presence & - & - & - & - & - & - & - & - & 15 & 100 \\
\hline 2 & Punctuality & - & - & - & - & 9 & 60 & 5 & 33.3 & 1 & 6.7 \\
\hline 3 & Readiness & - & - & - & - & - & - & 9 & 60 & 6 & 40 \\
\hline 4 & activity & - & - & - & - & 1 & 6.7 & 3 & 20 & 11 & 75.3 \\
\hline 5 & Child attention & - & - & - & - & - & - & 5 & 33.3 & 10 & 66.7 \\
\hline 6 & Enthusiastic & - & - & - & - & 1 & 6.7 & 5 & 33.3 & 9 & 60 \\
\hline 7 & How to play children & - & - & - & - & 1 & 6.7 & 6 & 40 & 8 & 53.3 \\
\hline 8 & Seriousness & - & - & - & - & - & - & 5 & 33.3 & 10 & 66.7 \\
\hline 9 & Structured play & - & - & - & - & - & - & - & - & 6 & 40 \\
\hline 10 & Children's activity & - & - & - & - & - & - & - & - & 9 & 60 \\
\hline
\end{tabular}

Table 7. Results of observation of children's activity at Santo' game first meeting

\begin{tabular}{cccccccccccc}
\hline & \multicolumn{10}{c}{ SCORE } \\
\cline { 3 - 13 } No & Assessment Aspects & \multicolumn{1}{c}{1} & \multicolumn{1}{c}{2} & \multicolumn{1}{c}{3} & 4 & \multicolumn{2}{c}{5} \\
\cline { 3 - 13 } & & F & $\%$ & F & $\%$ & F & $\%$ & F & $\%$ & F & $\%$ \\
\hline 1 & Presence & - & - & - & - & - & - & - & - & 15 & 100 \\
\hline 2 & Punctuality & - & - & 10 & 66.7 & 2 & 13.3 & - & - & - & - \\
\hline 3 & Readiness & 10 & 66.7 & 5 & 33.3 & - & - & - & - & - & - \\
\hline 4 & activity & 6 & 40 & 7 & 46.7 & 2 & 13.3 & - & - & - & - \\
\hline 5 & Child attention & 6 & 40 & 9 & 60 & - & - & - & - & - & - \\
\hline 6 & Enthusiastic & 4 & 26.7 & 11 & 73.3 & - & - & - & - & - & - \\
\hline 7 & How to play children & 4 & 26.7 & 10 & 66.7 & 1 & 6.7 & - & - & - & - \\
\hline 8 & Seriousness & 6 & 40 & 9 & 60 & - & - & - & - & - & - \\
\hline 9 & Structured play & 10 & 66.7 & 5 & 33.3 & - & - & - & - & - & - \\
\hline 10 & Children's activity & 9 & 60 & 6 & 40 & - & - & - & - & - & - \\
\hline
\end{tabular}

Table 8. Observation results of children's activities in Santo' game last meeting

\begin{tabular}{|c|c|c|c|c|c|c|c|c|c|c|c|}
\hline \multirow{3}{*}{ No } & \multirow{3}{*}{ Assessment Aspects } & \multicolumn{10}{|c|}{ SCORE } \\
\hline & & \multicolumn{2}{|c|}{1} & \multicolumn{2}{|c|}{2} & \multicolumn{2}{|c|}{3} & \multicolumn{2}{|r|}{4} & \multicolumn{2}{|c|}{5} \\
\hline & & $\mathrm{F}$ & $\%$ & $\mathrm{~F}$ & $\%$ & $\mathrm{~F}$ & $\%$ & $\mathrm{~F}$ & $\%$ & $\mathrm{~F}$ & $\%$ \\
\hline 1 & Presence & - & - & - & - & - & - & - & - & 15 & 100 \\
\hline 2 & Punctuality & - & - & - & - & 6 & 40 & 8 & 53.3 & 1 & 6.7 \\
\hline 3 & Readiness & - & - & - & - & - & - & 5 & 33.3 & 10 & 66.7 \\
\hline 4 & activity & - & - & - & - & - & - & 3 & 20 & 12 & 80 \\
\hline 5 & Child attention & - & - & - & - & - & - & 5 & 33.3 & 10 & 66.7 \\
\hline 6 & Enthusiastic & - & - & - & - & - & - & 5 & 33.3 & 10 & 66.7 \\
\hline 7 & How to play children & - & - & - & - & - & - & 5 & 33.3 & 10 & 66.7 \\
\hline 8 & Seriousness & - & - & - & - & - & - & 7 & 46.7 & 8 & 53.3 \\
\hline 9 & Structured play & - & - & - & - & - & - & 5 & 33.3 & 10 & 66.7 \\
\hline 10 & Children's activity & - & - & - & - & - & - & 5 & 33.3 & 10 & 66.7 \\
\hline
\end{tabular}

Table 9. Observation results of children's activities in Asing games first meeting

\begin{tabular}{|c|c|c|c|c|c|c|c|c|c|c|c|}
\hline \multirow{3}{*}{ No } & \multirow{3}{*}{ Assessment Aspects } & \multicolumn{10}{|c|}{ SCORE } \\
\hline & & \multicolumn{2}{|c|}{1} & \multicolumn{2}{|r|}{2} & \multicolumn{2}{|c|}{3} & \multicolumn{2}{|c|}{4} & \multicolumn{2}{|c|}{5} \\
\hline & & $\mathrm{F}$ & $\%$ & $\mathrm{~F}$ & $\%$ & $\mathrm{~F}$ & $\%$ & $\mathrm{~F}$ & $\%$ & $\mathrm{~F}$ & $\%$ \\
\hline 1 & Presence & - & - & - & - & - & - & - & - & 15 & 100 \\
\hline 2 & Punctuality & 7 & 46.7 & 8 & 53.3 & - & - & - & - & - & - \\
\hline 3 & Readiness & 7 & 46.7 & 5 & 33.3 & 3 & 20 & - & - & - & - \\
\hline
\end{tabular}




\begin{tabular}{cccccccccccc}
\hline 4 & activity & 7 & 46.7 & 5 & 33.3 & 3 & 20 & - & - & - & - \\
\hline 5 & Child attention & 8 & 53.3 & 7 & 46.7 & - & - & - & - & - & - \\
\hline 6 & Enthusiastic & 9 & 60 & 6 & 40 & - & - & - & - & - & - \\
\hline 7 & How to play children & 9 & 60 & 6 & 40 & - & - & - & - & - & - \\
\hline 8 & Seriousness & 11 & 73.3 & 4 & 26.7 & - & - & - & - & - & - \\
\hline 9 & Structured play & 10 & 66.7 & 9 & 60 & - & - & - & - & - & - \\
\hline 10 & Children's activity & 9 & 60 & 6 & 40 & - & - & - & - & - & - \\
\hline
\end{tabular}

Table 10. Observation results of children's activities in Asing games last meeting

\begin{tabular}{|c|c|c|c|c|c|c|c|c|c|c|c|}
\hline \multirow{3}{*}{ No } & \multirow{3}{*}{ Assessment Aspects } & \multicolumn{10}{|c|}{ SCORE } \\
\hline & & \multicolumn{2}{|c|}{1} & \multicolumn{2}{|c|}{2} & \multicolumn{2}{|c|}{3} & \multicolumn{2}{|r|}{4} & \multicolumn{2}{|c|}{5} \\
\hline & & $\mathrm{F}$ & $\%$ & $\mathrm{~F}$ & $\%$ & $\mathrm{~F}$ & $\%$ & $\mathrm{~F}$ & $\%$ & $\mathrm{~F}$ & $\%$ \\
\hline 1 & Presence & - & - & - & - & - & - & - & - & 15 & 100 \\
\hline 2 & Punctuality & - & - & - & - & - & - & 4 & 26.7 & 11 & 73.3 \\
\hline 3 & Readiness & - & - & - & - & - & - & 5 & 33.3 & 10 & 66.7 \\
\hline 4 & activity & - & - & - & - & - & - & 6 & 40 & 9 & 60 \\
\hline 5 & Child attention & - & - & - & - & - & - & 5 & 33.3 & 10 & 66.7 \\
\hline 6 & Enthusiastic & - & - & - & - & - & - & 4 & 26.7 & 11 & 73.3 \\
\hline 7 & How to play children & - & - & - & - & - & - & 6 & 40 & 9 & 60 \\
\hline 8 & Seriousness & - & - & - & - & - & - & 5 & 33.3 & 10 & 66.7 \\
\hline 9 & Structured play & - & - & - & - & - & - & 5 & 33.3 & 10 & 66.7 \\
\hline 10 & Children's activity & - & - & - & - & - & - & 5 & 33.3 & 10 & 66.7 \\
\hline
\end{tabular}

Table 11. Observation results of children's activities in the Saureka-reka game first meeting

\begin{tabular}{cccccccccccc}
\hline & & \multicolumn{10}{c}{ SCORE } \\
\cline { 3 - 14 } No & Assessment Aspects & \multicolumn{1}{c}{1} & \multicolumn{10}{c}{3} & \multicolumn{2}{c}{3} & \multicolumn{2}{c}{5} \\
\cline { 3 - 14 } & & F & $\%$ & F & $\%$ & F & $\%$ & F & $\%$ & F & $\%$ \\
\hline 1 & Presence & - & - & - & - & - & - & - & - & 15 & 100 \\
\hline 2 & Punctuality & 4 & 26.7 & 11 & 73.3 & - & - & - & - & - & - \\
\hline 3 & Readiness & 6 & 40 & 9 & 60 & - & - & - & - & - & - \\
\hline 4 & activity & 4 & 26.7 & 11 & 73.3 & - & - & - & - & - & - \\
\hline 5 & Child attention & 5 & 33.3 & 10 & 66.7 & - & - & - & - & - & - \\
\hline 6 & Enthusiastic & 10 & 66.7 & 5 & 33.3 & - & - & - & - & - & - \\
\hline 7 & How to play children & 8 & 53.3 & 7 & 46.7 & - & - & - & - & - & - \\
\hline 8 & Seriousness & 6 & 40 & 9 & 60 & - & - & - & - & - & - \\
\hline 9 & Structured play & 7 & 46.7 & 8 & 53.3 & - & - & - & - & - & - \\
\hline 10 & Children's activity & 7 & 46.7 & 8 & 53.3 & - & - & - & - & - & - \\
\hline
\end{tabular}

Table 12. Observation results of children's activities in the Saureka-reka game the last meeting

\begin{tabular}{|c|c|c|c|c|c|c|c|c|c|c|c|}
\hline \multirow{3}{*}{ No } & \multirow{3}{*}{ Assessment Aspects } & \multicolumn{10}{|c|}{ SCORE } \\
\hline & & \multicolumn{2}{|c|}{1} & \multicolumn{2}{|c|}{2} & \multicolumn{2}{|c|}{3} & \multicolumn{2}{|r|}{4} & \multicolumn{2}{|c|}{5} \\
\hline & & $\mathrm{F}$ & $\%$ & $\mathrm{~F}$ & $\%$ & $\mathrm{~F}$ & $\%$ & $\mathrm{~F}$ & $\%$ & $\mathrm{~F}$ & $\%$ \\
\hline 1 & Presence & - & - & - & - & - & - & - & - & 15 & 100 \\
\hline 2 & Punctuality & - & - & - & - & - & - & 5 & 33.3 & 10 & 66.7 \\
\hline 3 & Readiness & - & - & - & - & 1 & 6.7 & 7 & 46.7 & 7 & 46.7 \\
\hline 4 & activity & - & - & - & - & - & - & 4 & 26.7 & 11 & 73.3 \\
\hline 5 & Child attention & - & - & - & - & - & - & 6 & 40 & 9 & 60 \\
\hline 6 & Enthusiastic & - & - & - & - & - & - & 6 & 40 & 9 & 60 \\
\hline 7 & How to play children & - & - & - & - & - & - & 5 & 33.3 & 10 & 66.7 \\
\hline 8 & Seriousness & - & - & - & - & - & - & 5 & 33.3 & 10 & 66.7 \\
\hline 9 & Structured play & - & - & - & - & - & - & 4 & 26.7 & 11 & 73.3 \\
\hline 10 & Children's activity & - & - & - & - & - & - & - & - & 10 & 66.7 \\
\hline
\end{tabular}


Based on the results of a preliminary study on 15 students at Joy Kids Kindergarten by observing during learning, in general, the prosocial behaviour of students has not yet appeared to reach $72 \%$, and this shows that prosocial behaviour is still lacking in these students. It can be concluded that the majority of students need learning that can improve their prosocial behaviour both within the school environment and outside the school environment.

What is the level of validity and practicality of Outdoor learning modules based on traditional games to improve prosocial behaviour of young children?

Outdoor learning modules are created or compiled using 4 (four) traditional game materials (Ular Tangga Game, Santo' Game, Asing Game, Saureka Game) which are equipped with learning scenarios that can help educators in carrying out outdoor learning activities. The material provided in the form of games can see the affective domain of students.

The level of validity and practicality were assessed from three experts namely Dr PWT, M.Pd. and Dr AS, M.Sc. Kons, as an expert in early childhood education and as an expert in guidance and counselling. Other experts are practitioners in the field/school is HN, S.Pd.

a) Utility

Table 13. Results of the assessment of module usability tests by experts 1, 2 and 3

\begin{tabular}{cccccc}
\hline \multirow{2}{*}{ Questions } & \multicolumn{5}{c}{ Expert Rating } \\
& Expert 1 & Expert 2 & Expert 3 & Total & $\%$ \\
\hline 1 & 4 & 4 & 4 & 12 & 100 \\
2 & 4 & 3 & 4 & 11 & 91.67 \\
3 & 3 & 3 & 4 & 10 & 83.33 \\
4 & 4 & 4 & 4 & 12 & 100 \\
5 & 4 & 4 & 4 & 12 & 100 \\
\hline Total & 19 & 18 & 20 & 57 & \\
\hline$\%$ & 95 & 90 & 100 & & 95 \\
\hline
\end{tabular}

Usability test results with 5 acceptability questions to assess the usefulness of traditional game-based outdoor learning modules evaluated by three experts. Each question contained an answer using a scale of $1-4$. The assessment given by the three experts on the module usability test questionnaire was the first expert giving a value of $19(95 \%)$, the second expert giving a value of $18(90 \%)$, and the third expert giving value by $20(100 \%)$. Each question obtained data as follows, the first, fourth and fifth questions by $100 \%$, for the second question by $91.67 \%$ and the third question by $83.33 \%$. Based on the value of each question, an average percentage of usability tests that have been carried out is $95 \%$, so that it can be known outdoor learning modules based on traditional games to improve prosocial behaviour of young children designed by researchers considered useful for use by educators and students in the park a child.

b) Feasibility

Tabel 14. Results of the module feasibility assessment by experts 1, 2 and 3

\begin{tabular}{|c|c|c|c|c|c|}
\hline \multirow{2}{*}{ Questions } & \multicolumn{3}{|c|}{ Expert Rating } & \multirow{2}{*}{ Total } & \multirow{2}{*}{$\%$} \\
\hline & Expert 1 & Expert 2 & Expert 3 & & \\
\hline 1 & 4 & 4 & 4 & 12 & 100 \\
\hline 2 & 4 & 3 & 4 & 11 & 91.67 \\
\hline 3 & 3 & 3 & 4 & 10 & 83.33 \\
\hline 4 & 4 & 3 & 4 & 11 & 91.67 \\
\hline 5 & 4 & 4 & 4 & 12 & 100 \\
\hline 6 & 3 & 3 & 4 & 10 & 83.33 \\
\hline Total & 22 & 20 & 24 & 57 & \\
\hline$\%$ & 91.67 & 83.33 & 100 & & 91.67 \\
\hline
\end{tabular}

Based on Table 2. the results of the feasibility test with 6 acceptability questions to assess the use of traditional game based outdoor learning modules which were assessed by three experts. Each question contained an answer 
using a scale of 1-4. The assessment given by the three experts on the module usability test questionnaire was the first expert giving a score of $22(91.67 \%)$, the second expert giving a score of $20(83.33 \%)$, and the third expert gives a score of $24(100 \%)$. Each question obtained the following data, the first and fifth questions at $100 \%$, for the second and fourth questions at $91.67 \%$ and the third and sixth questions at $83.33 \%$. Based on the value of each question, an average percentage of usability tests that have been carried out is $91.67 \%$, so that it can be known outdoor learning modules based on traditional games to improve early childhood prosocial behaviour designed by researchers deemed appropriate for use by educators and students in kindergarten.

c) Accuracy

Tabel 15. Results of assessment of accuracy tests modules by experts 1, 2 and 3

\begin{tabular}{cccccc}
\hline Questions & Expert 1 & $\begin{array}{c}\text { Expert Rating } \\
\text { Expert 2 }\end{array}$ & Expert 3 & Total & $\%$ \\
\hline 1 & 4 & 4 & 4 & 12 & 100 \\
2 & 4 & 3 & 4 & 11 & 91.67 \\
3 & 4 & 3 & 4 & 11 & 91.67 \\
4 & 3 & 4 & 4 & 11 & 91.67 \\
5 & 4 & 3 & 4 & 11 & 91.67 \\
6 & 4 & 3 & 4 & 11 & 91.67 \\
\hline Total & 23 & 20 & 24 & 57 & \\
\hline$\%$ & 95.83 & 83.33 & 100 & & 93.06 \\
\hline
\end{tabular}

Based on Table 3. Accuracy test results with 6 acceptability questions to assess the use of traditional game-based outdoor learning modules assessed by three experts. Each question contained an answer using a scale of $1-4$. The assessment given by the three experts on the module usability test questionnaire was the first expert giving a score of $23(95.83 \%)$, the second expert giving a score of $20(83.33 \%)$, and the third expert gives a score of $24(100 \%)$. Each question obtained the following data, the first question was $100 \%$, and for the second to sixth questions was $91.67 \%$. Based on the value of each question, an average percentage of usability tests that have been carried out is $93.06 \%$, so that it can be seen that outdoor learning modules based on traditional games to improve prosocial behaviour of young children designed by researchers are considered appropriate for use by educators and students in kindergarten.

\section{Discussion}

This study aims to determine the prosocial behaviour of students in Joy Kids kindergarten Makassar, to produce outdoor learning modules based on traditional games that are acceptable for improving prosocial behaviour of young children, and to find out whether the outdoor learning modules based on traditional games produced can improve behaviour prosocial students at Joy Kids Kindergarten, Makassar.

Knowing the description of students' prosocial behaviour at school, researchers conducted data collection by making direct observations on students. The observations made are based on four indicators of prosocial behaviour, namely: cooperation, love to help, sharing with friends, and respecting friends. Three experts validated the validation of the observation sheet conducted on students. Initial description of students' prosocial behaviour in the Joy Kids Kindergarten, Makassar City based on the results of initial observations made on 15 students, the development of prosocial behaviour of students in learning is said to not meet the criteria because of the attainment of the level of development of prosocial behaviour of students $\pm 70 \%$ of children develop not as expected.

In addition to direct observation of the activities of students at the Joy Kids Kindergarten, Makassar, researchers also conducted interviews with teachers. Based on the results of interviews with teachers that students at the Kindergarten have not been too adapted to their friends and prosocial behaviour, namely cooperation, love to help, like to share with friends, and appreciate friends are not also visible in the daily lives of students. Students were sometimes just busy with themselves.

After doing a traditional game based outdoor learning, the teacher feels the use of traditional game based outdoor learning because by doing outdoor learning it can help students adapt to their friends and environment and with outdoor learning can see students' prosocial behaviour directly.

An acceptable module will be produced by conducting a validation test on three experts, namely two experts in the field of education and early childhood education who have a doctorate (S3), while practitioners in schools are 
selected by teachers who have served 7 years 6 months as a teacher at the Kids Joy Kindergarten. Based on the results of the three experts obtained an assessment of the utility (utility) of $95 \%$, while for the feasibility test the results obtained by $91.67 \%$ and for the test of accuracy (obtained) the results obtained by $93.06 \%$. Based on the results obtained from the usability test, feasibility test, and accuracy test, the outdoor learning module based on traditional games to improve prosocial behaviour in early childhood is appropriate for use in school.

\section{Conclusion}

Outdoor learning modules based on traditional games produced have been accepted from the results of the assessment of the utility of $95 \%$, the feasibility of $91.67 \%$, and the accuracy of $93.06 \%$, the results of the validation of two an expert in education and an education practitioner.

The effectiveness of traditional learning-based outdoor learning modules used can improve prosocial behaviour of early childhood. At the beginning of learning, students do not show prosocial behaviour, and prosocial behaviour began to appear at the second meeting until the last meeting. The Santo' game for indicators of collaboration as many as $12(80 \%)$ of students developed very well, for indicators of helpfulness as many as $13(86.7 \%)$ students developed very well, for indicators of sharing with friends as many as $13(86.7 \%)$ participants students develop very well, and for indicators of respect for friends as many as $13(86.7 \%)$ students develop very well. The Santo' game for cooperation indicators as many as $11(73.3 \%)$ students develop very well, for indicators like helping as many as $12(80 \%)$ students develop very well, for indicators share with friends as many as $12(80 \%)$ students develop very good, and for the indicator of respect for friends as many as $12(80 \%)$ students develop very well. The Asing games for cooperation indicators as many as $10(66.7 \%)$ students developed very well, for indicators like helping as many as $12(80 \%)$ students developed very well, for indicators of sharing with friends as many as 11 (73.3\%) students developed very well, and for indicators of respecting friends as many as $12(80 \%)$ students developed very well. The Saureka-game for indicators of cooperation as many as $11(73.3 \%)$ students developed very well, for indicators like helping as many as $10(66.7 \%)$ students developed very well, for indicators of sharing with friends as many as $12(80 \%)$ students develop very well, and for indicators respect friends as much as 10 $(66.7 \%)$ students develop very well. Based on this percentage, there was a change in prosocial behaviour of early childhood students, but previously it did not show any prosocial behaviour that developed very well.

\section{Acknowledgements}

The first author is thankful to Professor Syamsul Bahri Thalib and Professor Muhammad Arifin Ahmad (State University of Makassar), Dr. Andi Asrifan (Faculty of Teachers Training and Education at Muhammadiyah University of Sidenreng Rappang) for providing great assistance for this article. The first author addresses thanks to Ministry of Education and culture of Indonesia for the all support during her study.

\section{References}

Abdulhak, A. (2002). Memposisikan Pendidikan Anak Usia Dini dalam Sistem Pendidikan Nasional. Buletin PADU, Agustus.

Anonymous. (1989). Kamus Besar Bahasa Indonesia. Jakarta: Balai Pustaka

Anwar, S. (2010). Metode Penelitian. Yogyakarta: Pustaka pelajar.

Arizandi, A. (2018). Outdoor Learning Activities on the Second Year Students' Reading Comprehension of English Education Department, UIN Alauddin Makassar (Doctoral dissertation, Universitas Islam Negeri Alauddin Makassar).

Asih, G. Y., \& Pratiwi, M. M. S. (2010). Perilaku prososial ditinjau dari empati dan kematangan emosi. Jurnal psikologi umk: Pitutur, 1(1), 33-42.

Ayotte-Beaudet, J. P., Potvin, P., Lapierre, H. G., \& Glackin, M. (2017). Teaching and learning science outdoors in schools' immediate surroundings at K-12 levels: A meta-synthesis. EURASIA Journal of Mathematics, Science and Technology Education, 13(8), 5343-5363. https://doi.org/10.12973/eurasia.2017.00833a

Batson, C. D. (1998). Altruism and prosocial behavior. In D. T. Gilbert, S. T. Fiske, \& G. Lindzey (Eds.), The handbook of social psychology (pp. 282-316). McGraw-Hill.

Becker, C., Lauterbach, G., Spengler, S., Dettweiler, U., \& Mess, F. (2017). Effects of regular classes in outdoor education settings: A systematic review on students' learning, social and health dimensions. International Journal of Environmental Research and Public Health, 14(5), 485. https://doi.org/10.3390/ijerph14050485

Bilton, H. (2010). Outdoor learning in the early years: Management and innovation. Routledge. https://oi.org/10.4324/9780203860137 
Creswell, J. W. (2016). Educational Research: Planning, Conducting, and Evaluating Quantitative and Qualitative Research. Pearson.

Dillon, J., Rickinson, M., Teamey, K., Morris, M., Choi, M. Y., Sanders, D., \& Benefield, P. (2017). The value of outdoor learning: Evidence from research in the UK and elsewhere. In Towards a Convergence Between Science and Environmental Education: The selected works of Justin Dillon (pp. 179-185). Abingdon, Oxon: Taylor \& Francis. https://doi.org/10.4324/9781315730486

Ferreira, T., Cadima, J., Matias, M., Vieira, J. M., Leal, T., \& Matos, P. M. (2016). Preschool children's prosocial behavior: The role of mother-child, father-child and teacher-child relationships. Journal of Child and Family Studies, 25(6), 1829-1839. https://doi.org/10.1007/s10826-016-0369-x

Gustiana, D., Ali, M., \& Miranda, D. (2017). Penerapan Pembelajaran Outdoor pada Anak Usia 5-6 Tahun kelompok B2 di TK Immanuel II. Jurnal Pendidikan dan Pembelajaran Khatulistiwa, 6(3). Retrieved from https://jurnal.untan.ac.id/index.php/jpdpb/article/view/18869

Huda, M. (2013). Model-Model Pengajaran dan Pembelajaran. Yogyakarta: Pustaka Pelajar.

Hurlock, E. B. (2003). Perkembangan Anak. Jakarta: Erlangga

Husamah. (2013). Pembelajaran Luar Kelas Outdoor Learning. Jakarta: Prestasi Pustaka raya.

Kervinen, A., Uitto, A., \& Juuti, K. (2018). How fieldwork-oriented biology teachers establish formal outdoor education practices. Journal of Biological Education. https://doi.org/10.1080/00219266.2018.1546762

Khasanah, I., Prasetyo, A., \& Rakhmawati, E. (2011). Permainan tradisional sebagai media stimulasi aspek perkembangan anak usia dini. PAUDIA: Jurnal Penelitian dalam Bidang Pendidikan Anak Usia Dini, 1(1). https://doi.org/10.26877/paudia.v1i1.261

Lloyd, A., \& Gray, T. (2014). Place-based outdoor learning and environmental sustainability within Australian Primary Schools. Journal of Sustainability Education, 1(Sep).

McGuire, W. J. (1994). Uses of historical data in psychology: Comments on Münsterberg (1899). Psychological Review, 101(2), 243-247. https://doi.org/10.1037/0033-295X.101.2.243

Nisa, J. (2015). Outdoor learning sebagai metode pembelajaran ips dalam menumbuhkan karakter peduli lingkungan. SOSIO-DIDAKTIKA: Social Science Education Journal, 2(1), 1-11. https://doi.org/10.15408/sd.v2i1.1339

Norðdahl, K., \& Jóhannesson, I. Á. (2016). 'Let's go outside': Icelandic teachers' views of using the outdoors. Education 3-13, 44(4), 391-406. https://doi.org/10.1080/03004279.2014.961946

Nyoman, S. D. (2013). Ilmu Pembelajaran: Klasifikasi Variabel untuk Pengembangan Teori dan Penelitian.

Parmin, \& Aminah, S. (2009). Aktivitas Peserta Didik Dalam Pembelajaran IPA melalui Lesson Study. Jurnal Varia Pendidikan, 21(1), 1-11.

Peppler, K. (Ed.). (2017). The SAGE encyclopedia of out-of-school learning. Sage Publications. https://doi.org/10.4135/9781483385198

Perdani, P. A. (2013). Peningkatan Keterampilan Sosial Melalui Metode Bermain Permainan Tradisional pada Anak TK B. Jurnal Pendidikan Usia Dini, 7(2). Retrieved from http://journal.unj.ac.id/unj/index.php/jpud/article/view/3879

Rochma, L. I. (2012). Model Pembelajaran Outdoor Untuk Anak Usia Dini. Jurnal Pedagogia, 1(2), 173-188. https://doi.org/10.21070/pedagogia.v1i2.40

Schroeder, D. A., Penner, L. A., Dovidio, J. F., \& Piliavin, J. A. (1995). The psychology of helping and altruism: Problems and puzzles. New York: McGraw-Hill.

Sujiono, Y. N. (2009). Konsep Dasar Pendidikan Anak Usia Dini. Jakarta: PT Indeks

Sukiminiandari, Y. P., Agus, S. B., \& Yetti, S. (2015). Pengembangan Modul Pembelajaran Fisika dengan Pendekatan Saintifik. Prosiding Seminar Nasional Fisika (E-Journal) SNF2015 (Vol. 4). Retrieved from http://snf-unj.ac.id/kumpulan-prosiding/snf2015

Syahrir, S., \& Susilawati, S. (2015). Pengembangan Modul Pembelajaran Matematika Siswa SMP. Jurnal Ilmiah Mandala Education, 1(2), 162-171.

Taylor, L. J., \& Zwaan, R. A. (2008). Motor resonance and linguistics focus. Quarterly Journal of Experimantal Psychology, 61, 896-904. https://doi.org/10.1080/17470210701625519 
Tinne, R. D. (2012). Perilaku Prososial Ditelaah Berdasarkan Gemder. Skripsi Jurusan Psikologi FIP UPI. Bandung.

Utari, R. (2012). Taksonomi Bloom Apa dan Bagaimana Menggunakannya.

Vera, A. (2012). Metode mengajar anak di luar kelas (outdoor study). Yogyakarta: Divapress.

Wahab, A. (2017). Pengembangan Modul Pembelajaran Literasi Statistika (Analisis Regresi Linear Sederhana dengan R). Disertasi Universitas Negeri Makassar.

Wu, H. T., Tseng, S. F., Wu, P. L., \& Chen, C. M. (2016). The Relationship between Parent-Child Interactions and Prosocial Behavior among Fifth-and Sixth-Grade Students: Gratitude as a Mediating Variable. Universal Journal of Educational Research, 4(10), 2373-2385. https://doi.org/10.13189/ujer.2016.041016

Yıldırım, G., \& Akamca, G. Ö. (2017). The effect of outdoor learning activities on the development of preschool children. South African Journal of Education, 37(2). https://doi.org/10.15700/saje.v37n2a1378

\section{Copyrights}

Copyright for this article is retained by the author(s), with first publication rights granted to the journal.

This is an open-access article distributed under the terms and conditions of the Creative Commons Attribution license (http://creativecommons.org/licenses/by/4.0/). 